\title{
Plant Species Diversity and Degree of Homogeneity after the 2010 Eruption of Mount Merapi, Indonesia
}

\author{
Whisnu Febry Afrianto $^{1 *}$, Agus Hikmat $^{2}$, Didik Widyatmoko ${ }^{3}$ \\ ${ }^{1}$ Ecosystem and Biodiversity (Ecosbio), Indonesia \\ ${ }^{2}$ Department of Forest Resource Conservation and Ecotourism, IPB University, Indonesia \\ ${ }^{3}$ Research Center for Plant Conservation and Botanic Gardens, Indonesian Institute of Sciences, Indonesia \\ *Email: whisnu.afrianto@gmail.com \\ Submitted: 21 February 2020. Revised: 28 June 2020. Accepted: 7 August 2020
}

\begin{abstract}
The eruption in 2010 of Merapi Mount changed the diversity of plant species. The objective of this research was to investigate the diversity of plant species on Mount Merapi National Park (MMNP). The sampling area was divided into three different levels of damage (heavy, medium, and minor). The research was conducted by using line-transect and quadrat method. The research was conducted by using line-transect and quadrat method. The research showed that Acacia decurrens has the highest Important Value Index (IVI) at the heavy damage area of Cangkringan Resort (CR) and Kemalang Resort (KR) as well as in minor damage area of Selo Resort (SR). The most important species at medium damage area of Dukun Resort (DR) were Albizia lopantha and Pinus merkusii. The pioneer species at Non-Cover Area (NCA) among others were Trema cannabina, Pityrogramma calomelanos, Imperata cylindrical, Buddleja asiatica, and Anaphalis javanica. Eupatorium riparium was the most important species of herb in all four locations based on SIMPER, but it was not dominant in NCA. The homogeneity of plant in Cangkringan Resort and Selo Resort $(\mathrm{C}<\mathrm{D}<\mathrm{E})$ were normally distributed, whereas NCA, DR, and KR (E $\geq D)$ were homogeneous. Analysis of non-metric multidimensional scaling and value of ANOSIM $\left(\mathrm{R}_{\mathrm{ANOSIM}}=0.69 ; \mathrm{p}=0.0001\right)$ demonstrated that all site locations have significance differences. This research was not only focusing on survey of vegetation diversity, but also frequency class distribution. Through this study of frequency of species provides a database for conservation biodiversity and restoration program.
\end{abstract}

Key words: Homogeneity; Mount Merapi; Plant Species Diversity; The 2010 Eruption

How to Cite: Afrianto, W. F., Hikmat, A., \& Widyatmoko, D. (2020). Plant Species Diversity and Degree of Homogeneity after the 2010 Eruption of Mount Merapi, Indonesia. Biosaintifika: Journal of Biology \& Biology Education, 12 (2), 274-281

DOI: http://dx.doi.org/10.15294/biosaintifika.v12i2.23525

\section{INTRODUCTION}

Ministry of Forestry Decree No. 134/MenhutII/2004 on May 4, 2004 assigned forest area of Mount Merapi to become Mount Merapi National Park (MMNP). The forest of Mount Merapi has a total area of 6,410 ha. It is located in the Central Java Province and Special Region of Yogyakarta. The existence of the Mount Merapi ecosystem is crucial for the surrounding community's livelihood and as a habitat for protected fauna and flora.

The eruption of Mount Merapi in 2010 resulted in damaged areas with several categories including 1242.16 ha $(20.21 \%)$ heavy damage, 1207.91 ha $(19.66 \%)$ medium damage, 2543.94 ha $(41.40 \%) \mathrm{mi}-$ nor damage, and 1151.46 ha $(18.74 \%)$ lava flow area (MMNP, 2011a). Mount Merapi has dynamic ecology after the 2010 eruption. Invasive species after the 2010 eruption has been reported to be a threat in the habitat (Afrianto et al., 2017; Haryadi et al., 2019; Sutomo, 2019). On the other hand, trees distribution is impacted by average rainfall, elevation, and temperature in the springs area of Soloraya (Siswo et al., 2019). For example, there was an association between water-flow of springs and tree conditions where the spring circumstances declined after the trees degrad- ed. In a social aspect, Mount Merapi is part of belief in traditional knowledge, and it has a significant role in the surrounding community (Hendro, 2018; Wardyaningrum, 2019). In addition, the eruption also showed impacts on agriculture regarding land management (Rahayu et al., 2014; Rindrasih, 2013; Utami et al., 2018).

The succession process changes plant communities in their habitat (Raeval et al., 2012). This research aimed to identify plant species diversity after the 2010 eruption of Mount Merapi. The establishment of a plant diversity database of MMNP is a key factor in evaluating and monitoring the ecological dynamics of the area. It will also provide a systemic identification of the domination of species and the classification of native and invasive species.

\section{METHODS}

\section{Study area}

This research was conducted at the area of MMNP, particularly in Yogyakarta Province (Sleman District) and Central Java Province (Magelang, Klaten, and Boyolali Districts) (Figure 1). Placement of sample units representing the types of damage that occurred after the eruption in 2010 where heavy dam- 
age in Cangkringan Resort (CR), Non-Cover Area (NCA), and Resort Kemalang (KR). Heavy damage area has no vegetation left because it was burnt by volcanic ash. Medium damage in Dukun Resort (DR) that it was Pinus merkusii forest where the canopy and branches of trees were burnt by volcanic ash. The minor damage in Selo Resort (SR), it was almost like an intact forest (Gunawan et al., 2013).

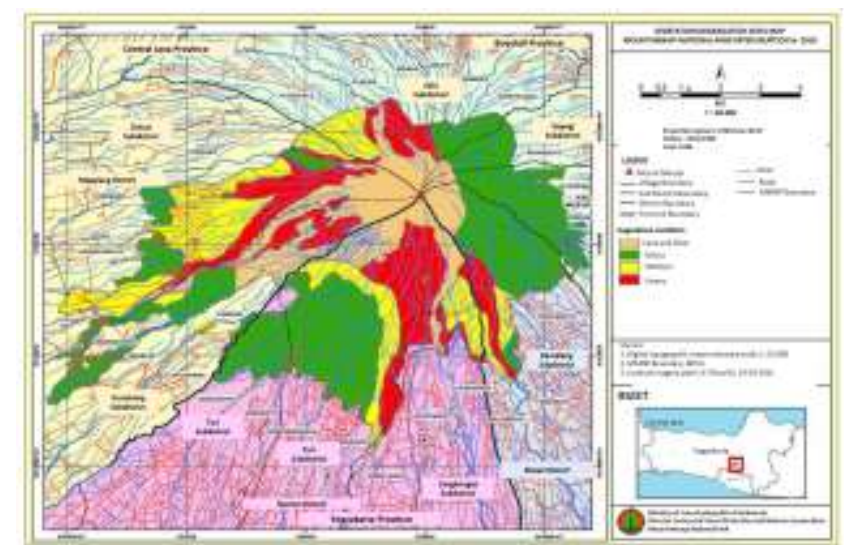

Figure 1. Map of sampling sites based on the degradation level of Merapi Mount after the eruption in 2010 (MMNP, 2011b).

\section{Sampling}

Determination of the number of sampling plots was conducted using the species-area curve. Total sample plots in each region were 1.6 ha (CR and NCA), 0.8 ha (KR), 0.4 ha (DR), and 0.4 ha (SR). The determination of the sampling sites was conducted by stratified sampling with a random start method. Analysis of vegetation in all study sites was conducted by using the line transect method in sampling units measuring $20 \mathrm{~m} \times 200 \mathrm{~m}$ with perpendicular direction to the contour line. Observations of vegetation were carried out on plots divided into plots measuring $20 \mathrm{~m}$ $\times 20 \mathrm{~m}$ (trees), $10 \times 10 \mathrm{~m}$ (poles), $5 \mathrm{~m} \times 5 \mathrm{~m}$ (saplings), and $2 \mathrm{~m} \times 2 \mathrm{~m}$ (seedlings, shrubs, and herbs respectively). The observation was also conducted at NCA from CR using a quadrat method in sampling units measuring $100 \times 100 \mathrm{~m}$, each consisting of a plot sized of $20 \mathrm{~m} \times 20 \mathrm{~m}$. The total plot was 75 plots from 3 quadrat sampling units (Kusmana, 2017).

\section{Data analysis}

The degree of homogeneity of the plant was determined using Raunkiaer Law of Frequency. Plant species were divided into five classes (Table 1) (Khan et al., 2012; Solikin, 2015). The criteria used were: (a) The normal distribution, if $\mathrm{A}>\mathrm{B}>\mathrm{C}$ or $\mathrm{C} \leq \mathrm{D}<\mathrm{E}$; (b) homogeneous, if $\mathrm{E} \geq \mathrm{D}$; (c) Heterogeneous, if $\mathrm{B}$, C, D are relatively high; (d) Disturbed, if $\mathrm{E}<\mathrm{D}$ (Suryawan et al., 2013).
Table 1. The classes of Raunkiaer Law of Frequency

\begin{tabular}{lc}
\hline Class & Species with frequency $(\%)$ \\
\hline A & $1-20$ \\
B & $21-40$ \\
C & $41-60$ \\
D & $61-80$ \\
E & $81-100$ \\
\hline
\end{tabular}

The importance value index (IVI) for herbs, shrubs, seedlings, and saplings were calculated by summing relative density and relative frequency. IVI of poles and trees were calculated by summing the relative density, relative frequency, and relative dominance (Roemantyo et al., 2012; Suryawan et al., 2015).

The model of dissimilarity in community composition was analyzed using ordination Non-Metric Multidimensional Scaling (NMDS). Non-parametric one way of analysis of similarity (ANOSIM) was used to test the significant difference. Finally, the analysis of similarity percentage (SIMPER) was calculated to evaluate the contribution of every species to dissimilarity among the group (Sutomo \& Faradila, 2013; Chakira et al., 2015). All of those analyses were done using PAST 3.06.

\section{RESULTS AND DISCUSSION}

A total of 135 species belonging to 64 families was collected in this study. Among 64 families found, the dominant families were Asteraceae (10 genus, 11 species), Poaceae (9 genus, 10 species), Euphorbiaceae (5 genus, 6 species), Moraceae ( 2 genus, 6 species), Fabaceae (5 genus, 5 species), and Rubiaceae (5 genus, 5 species). The other plant families were considered non-dominant since the number of species was less than five (Table 2). On the other hand, the species that had not been identified until species level (taxonomically name as "sp."). This shows that future research is needed, especially regarding plant identification until species level. Previous research showed that in Kalikuning, an area affected by the eruption in 2010, the dominant plant family was Rubiaceae (Sutomo and \& Fardila, 2013). Marler and del Moral (2011) also revealed that after the eruption at Mount Pinatubo, Luzon, Philippines, that area was dominated by Asteraceae, Fabaceae, and Poaceae.

The degree of homogeneity that was determined based on Raunkiaer Law of frequency (Figure 2). The result revealed the degree of homogeneity of $\mathrm{CR}$ and SR $(\mathrm{A}>\mathrm{B}>\mathrm{C}$ ) were normally distributed. Normal distribution means a forest community was in good condition (Suryawan et al., 2013). The frequency class distribution can be used to understand the indicator that controls the absence/presence and concentration of plant species (Danjuma et al., 2017). On 
the other hand, the degree of homogeneity of NCA, $\mathrm{DR}$, and KR $(\mathrm{E} \geq \mathrm{D})$ was homogeneous. The homogenous species distribution in nature means that uniform species diversity (Vaghasiya et al., 2015).

A. decurrens was one of 29 pioneer trees species after the eruption in 2010 (Gunawan et al., 2015). A. decurrens was dominant for seedling, pole, and tree in the heavy damage area (Figure 3). Even though, $A$. decurrens in $\mathrm{CR}$ was only found up to $1437 \mathrm{~m}$ asl after the 2010 eruption (Darmawan, 2015). In SR, which was the minor damage area, A. decurrens was also dominant in sapling, pole, and tree.
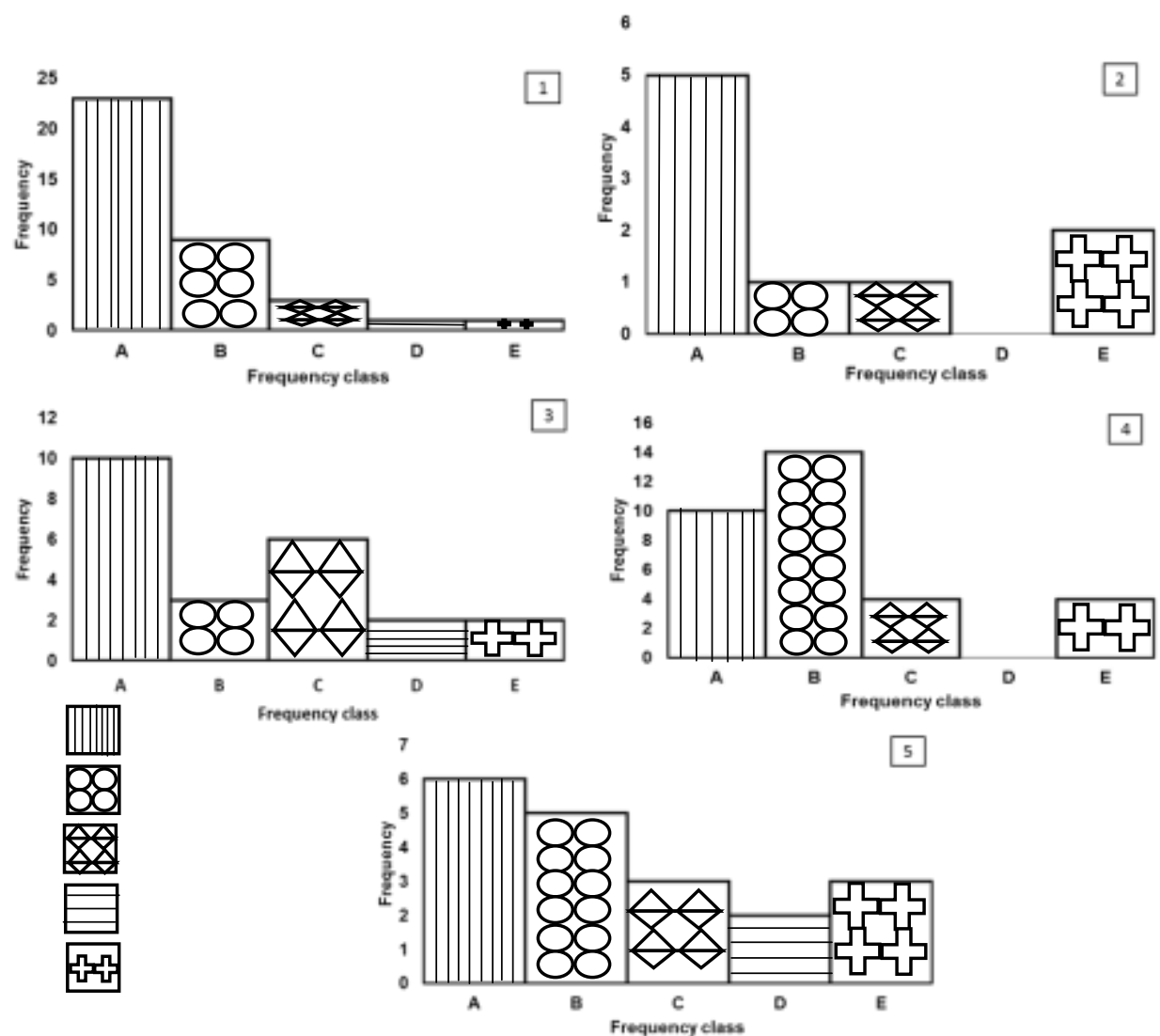

Figure 2. The degree of homogeneity after the 2010 eruption (1) Cangkringan Resort (CR), (2) Non-Cover Area (NCA), (3) Kemalang Resort (KR), (4) Dukun Resort (DR), and (5) Selo Resort (SR)

Table 2. Relative Density, relative frequency, relative dominance, and important value index of the top $3 \mathrm{im}-$ portant herb and shrub, seedling, sapling, pole, and tree species in all sampling sites

\begin{tabular}{|c|c|c|c|c|c|}
\hline Structure & Species & $\begin{array}{l}\text { Relative } \\
\text { density }(\%)\end{array}$ & $\begin{array}{l}\text { Relative } \\
\text { frequency } \\
(\%)\end{array}$ & $\begin{array}{l}\text { Relative } \\
\text { dominance } \\
(\%)\end{array}$ & $\begin{array}{l}\text { Important } \\
\text { value index } \\
(\%)\end{array}$ \\
\hline \multicolumn{6}{|l|}{$\mathrm{CR}$} \\
\hline \multirow[t]{3}{*}{ Seedlings } & Acacia decurrens & 43.24 & 37.50 & & 80.74 \\
\hline & Trema orientalis & 27.03 & 37.50 & & 64.53 \\
\hline & Maesa tetranda & 24.32 & 12.50 & & 36.82 \\
\hline \multirow[t]{3}{*}{ Saplings } & Acacia decurrens & 71.19 & 53.33 & & 124.52 \\
\hline & Trema orientalis & 14.40 & 23.33 & & 37.73 \\
\hline & Trema cannabina & 13.39 & 20.00 & & 33.39 \\
\hline \multirow[t]{3}{*}{ Poles } & Acacia decurrens & 96.15 & 89.19 & 95.57 & 280.91 \\
\hline & Trema cannabina & 2.88 & 8.11 & 3.56 & 14.55 \\
\hline & Trema orientalis & 0.96 & 2.70 & 0.87 & 4.53 \\
\hline \multirow[t]{2}{*}{ Trees } & Acacia decurrens & 57.14 & 60.00 & 50.01 & 167.15 \\
\hline & Trema orientalis & 42.86 & 40.00 & 49.99 & 132.85 \\
\hline \multirow[t]{2}{*}{ Herbs \& Shrubs } & Eupatorium riparium & 31.88 & 13.79 & & 45.67 \\
\hline & Pennisetum purpureum & 19.16 & 10.34 & & 29.50 \\
\hline
\end{tabular}


Whisnu Febry Afrianto et al. / Biosaintifika 12 (2) (2020): 274-281

\begin{tabular}{|c|c|c|c|c|c|}
\hline Structure & Species & $\begin{array}{l}\text { Relative } \\
\text { density (\%) }\end{array}$ & $\begin{array}{l}\text { Relative } \\
\text { frequency } \\
(\%)\end{array}$ & $\begin{array}{l}\text { Relative } \\
\text { dominance } \\
(\%)\end{array}$ & $\begin{array}{l}\text { Important } \\
\text { value index } \\
(\%)\end{array}$ \\
\hline & Isachne globosa & 10.82 & 5.91 & & 16.73 \\
\hline \multicolumn{6}{|l|}{ NCA } \\
\hline Seedlings & Trema cannabina & 100.00 & 100.00 & & 200.00 \\
\hline \multirow[t]{4}{*}{ Herbs \& Shrubs } & Pityrogramma calomelanos & 45.54 & 16.62 & & 61.12 \\
\hline & Imperata cylindrica & 40.93 & 15.96 & & 56.89 \\
\hline & Buddleja asiatica & 3.93 & 10.64 & & 14.03 \\
\hline & Anaphalis javanica & 5.32 & 7.71 & & 13.03 \\
\hline \multicolumn{6}{|l|}{ KR } \\
\hline \multirow[t]{3}{*}{ Seedlings } & Acmena sp & 50.00 & 50.00 & & 100.00 \\
\hline & Acacia decurrens & 37.50 & 25.00 & & 62.50 \\
\hline & Schima wallichii & 12.50 & 20.00 & & 32.50 \\
\hline Saplings & Acacia decurrens & 100.00 & 100.00 & & 200.00 \\
\hline Poles & Acacia decurrens & 100.00 & 100.00 & 100.00 & 300.00 \\
\hline \multirow[t]{2}{*}{ Trees } & Schima wallichii & 93.75 & 80.00 & 93.62 & 267.37 \\
\hline & Acacia decurrens & 6.25 & 20.00 & 6.32 & 32.57 \\
\hline \multirow[t]{3}{*}{ Herbs \& Shrubs } & Eupatorium riparium & 17.18 & 9.29 & & 26.47 \\
\hline & Borreria ocymoides & 13.90 & 4.92 & & 18.82 \\
\hline & Isachne globosa & 9.88 & 6.56 & & 16.44 \\
\hline \multicolumn{6}{|l|}{ DR } \\
\hline \multirow[t]{3}{*}{ Seedlings } & Callyandra calothyrsus & 34.88 & 31.25 & & 66.13 \\
\hline & Psidium guajava & 25.58 & 25.00 & & 50.58 \\
\hline & Ficus septica & 13.95 & 25.00 & & 38.95 \\
\hline \multirow[t]{3}{*}{ Saplings } & Pinus merkusii & 55.56 & 57.14 & & 112.70 \\
\hline & Albizia lopantha & 22.22 & 28.57 & & 50.79 \\
\hline & Psidium guajava & 22.22 & 14.29 & & 36.51 \\
\hline Poles & Albizia lopantha & 100.00 & 100.00 & 100.00 & 300.00 \\
\hline Trees & Pinus merkusii & 100.00 & 100.00 & 100.00 & 300.00 \\
\hline \multirow[t]{3}{*}{ Herbs \& Shrubs } & Pennisetum purpureum & 25.62 & 10.53 & & 36.15 \\
\hline & Eupatorium riparium & 12.36 & 10.53 & & 22.89 \\
\hline & Isachne globosa & 17.18 & 4.21 & & 21.39 \\
\hline \multicolumn{6}{|l|}{$\mathrm{SR}$} \\
\hline Seedlings & Lithocarpus sundaicus & 100.00 & 100.00 & & 200.00 \\
\hline Saplings & Acacia decurrens & 100.00 & 100.00 & & 200.00 \\
\hline Poles & Acacia decurrens & 100.00 & 100.00 & 100.00 & 300.00 \\
\hline \multirow[t]{2}{*}{ Trees } & Acacia decurrens & 66.67 & 66.67 & 20.93 & 154.27 \\
\hline & Cupressus sp & 33.33 & 33.33 & 79.07 & 145.73 \\
\hline \multirow[t]{3}{*}{ Herbs \& Shrubs } & Arundinella nepalensis & 38.12 & 12.31 & & 50.43 \\
\hline & Pennisetum purpureum & 28.54 & 13.85 & & 42.39 \\
\hline & Eupatorium riparium & 16.64 & 15.38 & & 32.02 \\
\hline
\end{tabular}

Note: $\mathrm{CR}=$ Cangkringan Resort, NCA = Non-Cover Area, RK = Resort Kemalang, DR = Dukun Resort, $\mathrm{SR}=$ Selo Resort.

Tree $(267.37 \%)$ of $S$. wallichii were dominant species in KR (Figure 3). It is because species of $S$. wallichii have the ability in adaptation from fire disturbance (Kusumastuti, 2017). S. wallichii in minor dam- age area has higher genetic diversity than in the moderate one (Baramantya et al., 2016). In addition, a number of alleles that have a lower frequency and contribution to affect the genetic variation. In nature, 
S. wallichii grows in altitudes between 750 and 2400 $\mathrm{m}$ asl (Khanduri et al., 2013). According to Khanduri et al., (2013), the reproduction of $S$. wallichii in altitude $750 \mathrm{~m}$ and $900 \mathrm{~m}$ asl is impacted by the variation in the floral phenology.
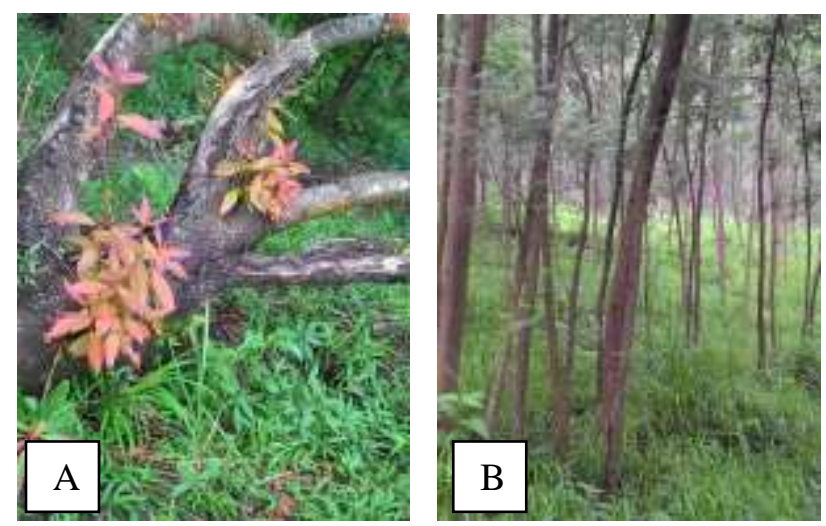

Figure 3. (A) Native species of $S$. wallichii vs (B) Invasive species of $A$. decurrens in MMNP after the 2010 eruption

The most important species in DR were seedling of $C$. calothyrsus $(66.13 \%)$, the sapling of $P$. merkusii (112.70\%), pole of A. lopantha (300.00\%), and the tree of $P$. merkusii (300.00\%). The secondary succession process in DR was showed by the blossoming of $P$. merkusii canopy. P. merkusii was dominant because this species was planted by Indonesian state forestry company (Perhutani) for forestry production. MMNP was trying to enrich its plant species diversity by changing a homogeneous to the heterogeneous forest.

NMDS ordination models of Bray Curtis dissimilarity in all site locations were clearly separated (Figure 4). NMDS stress value of $<0.20$ showed that ordinated models can be used (Gallmetzer \& Shultze, 2015). The result showed that species composition and abundance were significantly different between these sites as tested by ANOSIM $\left(\mathrm{R}_{\text {ANOSIM }}=0.69 ; \mathrm{p}=\right.$ 0.0001). The pairwise ANOSIM showed differences in each habitat (NCA vs. $\mathrm{CR}, \mathrm{R}=0.83 ; \mathrm{p}=0.0001$ ), (CR vs. $\mathrm{DR}, \mathrm{R}=-0.02 ; \mathrm{p}=0.59),(\mathrm{CR}$ vs. $\mathrm{KR}, \mathrm{R}=$ $0.14 ; \mathrm{p}=0.01)$, (CR vs. SR, $\mathrm{R}=0.13 ; \mathrm{p}=0.07$ ), (NCA vs. $\mathrm{DR}, \mathrm{R}=0.83 ; \mathrm{p}=0.0001$ ), (NCA vs. KR, $\mathrm{R}$ $=0.80 ; \mathrm{p}=0.0001),(\mathrm{NCA}$ vs. $\mathrm{SR}, \mathrm{R}=0.73 ; \mathrm{p}=$ 0.0001 ), (DR vs. $K R, R=0.33 ; p=0.0003$ ), (DR vs. $\mathrm{SR}, \mathrm{R}=0.46 ; \mathrm{p}=0.0001)$, (KR vs. $\mathrm{SR}, \mathrm{R}=0.27 ; \mathrm{p}=$ 0.002). Score 1 indicated that all samples within groups were more similar than from different groups, while score 0 denoted that there was no difference among groups. The result is similar to the configuration of NMDS ordination between burnt site (Kalikuning) and control site (Kaliurang) that the species composition and abundance was significantly different (Sutomo \& Fardila, 2013). That research also showed that B. occimoides and I. cylindrical were dominant plant species in the burnt site, whereas $E$. riparium was one of dominant plant species in the unburnt sites.

The most contributed species to the dissimilarity in all site locations were identified using SIMPER in Table 3. SIMPER result revealed that E. riparium was found in all sampling sites with a cumulative contribution value of $17.97 \%$. E. riparium is reported as an invasive species (Heystek et al., 2011). This species was dominant in four site locations (CR, SR, DR, and SR). The vegetation survey showed that E. riparium was also dominant in Plawangan (Natalia \& Handayani, 2013). Herbs and shrubs were dominant because the area has high light and open canopy (Sutomo \& Fardila, 2013).

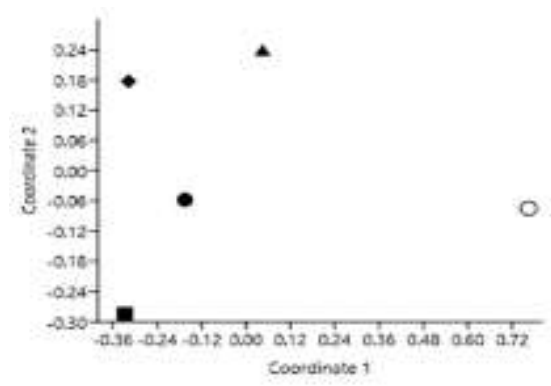

Figure 4. NMDS ordinations based on Bray-Curtis indices (with $\sqrt{ } \mathrm{x}$ transformed abundances) visualizing similarity relationships in species composition between Cangkringan Resort ( $\bullet$ ), Kemalang Resort $(\bullet)$, Dukun Resort (ם), Selo Resort ( $\bullet$ ), and NonCover Area ( $\bigcirc$ ); 2D Stress 0.00.

Mount Merapi is an active volcano, and the succession will be challenging to reach a climax stage, particularly in the pyroclastic flow areas. From 2010 to 2015, it was recorded that the status of Mount Merapi became alert status because of the rise of volcanic gas in 2014. Pyroclastic flows have been predicted to occur potential high-risk areas along the Opak and Gendol River (Yulianto, 2014).

Structure of vegetation after the 2010 eruption was affected by the abiotic environment conditions (Afrianto et al., 2016). The trait-based assessment can be used to identify the early risk of invasive plant species in the forest (Junaedi \& Mutaqien, 2018). The heavy damage area was dominated by $A$. decurrens, which was invasive species. The dominance of $A$. decurrens are correlated with temperature and slope conditions (Afrianto et al., 2017). The distribution of A. decurrens has been reported to be clumped (Untoro et al., 2017). The invasive species can inhibit growth and be competition to native species (Sutomo, 2019). The management of invasive species is an important part of the restoration. Thus, prevention of the widely distribution of invasive species can be done by planting native species, eradication, and biocontrol. 
Table 3. SIMPER analysis of species that contributes to the similarity in site similarity comparison

\begin{tabular}{|c|c|c|c|c|c|c|c|c|}
\hline \multirow[t]{2}{*}{ Species } & \multirow{2}{*}{$\begin{array}{c}\text { Average } \\
\text { dissimi- } \\
\text { larity }\end{array}$} & \multirow{2}{*}{$\begin{array}{l}\text { Contri- } \\
\text { bu- } \\
\text { tion } \%\end{array}$} & \multirow{2}{*}{$\begin{array}{c}\text { Cumu- } \\
\text { lative } \\
\%\end{array}$} & \multicolumn{5}{|c|}{ Mean abundance } \\
\hline & & & & $\mathrm{CR}$ & NCA & DR & $\mathrm{KR}$ & SR \\
\hline Acacia decurrens & 2.92 & 3.10 & 70.45 & 7.47 & 0.00 & 0.00 & 3.95 & 1.50 \\
\hline Acmena $\mathrm{sp}$ & 0.05 & 0.05 & 99.54 & 0.00 & 0.00 & 0.00 & 0.20 & 0.00 \\
\hline Albizia lopantha & 0.03 & 0.04 & 99.76 & 0.08 & 0.00 & 0.30 & 0.00 & 0.00 \\
\hline Anaphalis javanica & 0.54 & 0.57 & 94.30 & 0.00 & 1.25 & 0.00 & 0.00 & 0.00 \\
\hline Buddleja asiatica & 0.44 & 0.47 & 95.27 & 0.00 & 1.03 & 0.00 & 0.00 & 0.00 \\
\hline Callyandra calothirsus & 0.08 & 0.09 & 98.89 & 0.00 & 0.00 & 1.50 & 0.00 & 0.00 \\
\hline Cupressus sp & 0.00 & 0.00 & 100.00 & 0.00 & 0.00 & 0.00 & 0.00 & 0.10 \\
\hline Eupatorium riparium & 16.96 & 17.97 & 17.97 & 35.40 & 0.35 & 24.90 & 50.80 & 73.30 \\
\hline Borreria ocymoides & 2.50 & 2.65 & 73.10 & 0.23 & 0.00 & 0.20 & 41.00 & 0.00 \\
\hline Ficus septica & 0.03 & 0.04 & 99.79 & 0.00 & 0.00 & 0.60 & 0.00 & 0.00 \\
\hline Imperata cylindrica & 4.86 & 5.15 & 62.35 & 0.55 & 10.20 & 0.00 & 3.55 & 25.40 \\
\hline Isachne globosa & 7.86 & 8.34 & 51.54 & 12.10 & 0.00 & 34.60 & 29.20 & 11.80 \\
\hline Arundinella nepalensis & 9.59 & 10.16 & 43.20 & 7.10 & 0.00 & 7.30 & 29.50 & 168.00 \\
\hline Lithocarpus sundaicus & 0.01 & 0.01 & 99.98 & 0.00 & 0.00 & 0.00 & 0.00 & 0.10 \\
\hline Maesa tetranda & 0.11 & 0.11 & 98.60 & 0.23 & 0.00 & 0.00 & 0.00 & 0.00 \\
\hline Pennisetum purpureum & 14.21 & 15.07 & 33.04 & 21.40 & 0.00 & 51.60 & 23.70 & 126.00 \\
\hline Pinus merkusii & 0.35 & 0.37 & 96.49 & 0.00 & 0.00 & 5.20 & 0.00 & 0.00 \\
\hline Pityrogramma calomelanos & 4.72 & 5.00 & 67.35 & 0.00 & 11.50 & 0.00 & 0.00 & 0.00 \\
\hline Psidium guajava & 0.06 & 0.06 & 99.27 & 0.00 & 0.00 & 1.10 & 0.00 & 0.00 \\
\hline Schima wallichii & 0.10 & 0.11 & 98.70 & 0.00 & 0.00 & 0.00 & 0.75 & 0.00 \\
\hline Trema cannabina & 0.39 & 0.41 & 96.12 & 0.93 & 0.29 & 0.00 & 0.00 & 0.00 \\
\hline Trema orientalis & 0.42 & 0.44 & 95.71 & 1.23 & 0.00 & 0.00 & 0.00 & 0.00 \\
\hline
\end{tabular}

Note: $\mathrm{CR}=$ Cangkringan Resort, NCA $=$ Non-Cover Area, RK $=$ Resort Kemalang, DR $=$ Dukun Resort, $\mathrm{SR}=$ Selo Resort.

This research was not only focusing on the survey of vegetation diversity, but also frequency class distribution. Through the knowledge that succession is a dynamic process, the present study provides information for the conservation of native plants and restoration programs. The analysis of plant diversity can contribute to a comprehensive evaluation of its relation to the vegetation vulnerability to the volcano eruption. The other benefits from the assessment of plant species diversity are for environmental protection and sustainable management of natural resources in the area.

\section{CONCLUSION}

. The diversity of species in all sampling locations in Mount Merapi National Park was difference after the 2010 eruption. The range of homogeneity of vegetation in the Mount Merapi National Park consisted of normally distributed (CR and SR) and homogeneous (NCA, KR, and DR) vegetation.

\section{REFERENCES}

Afrianto, W. F., Hikmat, A., \& Widyatmoko, D. (2016). Floristic community and vegetation succession after the 2010 Eruption of Mount Merapi Central Jawa. Jurnal Biologi Indonesia, 12(2), 265-276.

Afrianto, W. F., Hikmat, A., \& Widyatmoko, D. (2017). Growth and habitat preference of Acacia decurrens Willd. (Fabaceae) after the 2010 eruption of Mount Merapi, Indonesia. AJAS, 05(1), 6572.

Baramantya, B., Indriko, S., Faida, L. R. W., \& Hadiyan, Y. (2016). Genetic diversity and natural regeneration of Schima wallichii (DC.) Korth. in Gunung Merapi National Park post merapi erup- 
tion 2010. Jurnal Pemuliaan Tanaman Hutan, 10(2), $111-121$.

Chakira, H., Ely-amine, A. M., Casacci, L. P., Ouledi, A., Wagan, T. A., Mabubu, J., Hua, H. X., He, Y. P., \& Balleto, E. (2015). The butterflies of Ngazidja and their main habitats significances. Journal of Biodiversity and Environmental Science, 7, 10-22.

Danjuma, M. N., Bindawa, A. A., Babankowa, I. A., \& Maiwada, B. (2017). Frequency class distribution of vegetation in the dryland of Northwestern Nigeria. American Journal of Biology and Life Sciences, 5(2), 7-12

Darmawan, N. S. (2015). Karakteristik habitat dan pola sebaran anggrung (Trema orientalis) pasca erupsi 2010 di Resort Cangkringan Taman Nasional Gunung Merapi (Unpublished bachelor's thesis), Universitas Gadjah Mada, Yogyakarta, Indonesia.

Gallmetzer, N., \& Shulze, C. (2015). Impact of oil palm agriculture on understory amphibians and reptiles: A Mesoamerican perspective. Global Ecology and Conservation, 4, 95-109.

Marler, T. E., \& del Moral, R. (2011). Primary succession along an elevation gradient 15 years after the eruption of Mount Pinatubo, Luzon, Philippines. Pacific Science, 65, 157 - 173.

Gunawan, H., Sugiarti, Wardani, M., Tata, M. H. L., \& Prajadinata. (2013). Restorasi ekosistem Gunung Merapi pascaerupsi. Bogor: Reseach and Development Centers of Conservation and Rehabilitation

Gunawan, H., Heriyanto, N. M., Subiandono, E., Mas'ud, A. F., \& Krisnawati, H. (2015). Invasi jenis eksotis pada areal terdegradasi pasca erupsi di Taman Nasional Gunung Merapi. Pros Sem Nas Masy Biodiv Indon, 1, 1027-1033.

Haryadi, Sunarto, \& Sugiyarto. (2019). Vegetation analysis of the Secondary Forest Area in Cangkringan Resort, Mount Merapi National Park. Jurnal Biodjati, 4(1), 50-57.

Hendro, E. P. (2018). Religiusitas Gunung Merapi. Endogami, 2(1), 22-29.

Heystek, F., Wood, A. R., Neser, S., \& Kistensamy, Y. (2011). Biological control of two Ageratina species (Asteraceae: Eupatorieae) in South Africa. African Entomology, 19 (2), 208-2016.

Junaedi, D. I., \& Mutaqien, Z. (2018). Predicting invasion probability from Botanic Gardens using exotic species traits. Biosaintifika, 10(3), 539-545.

Khan, M., Hussain, F., \& Musharaf, S. (2012). Degree of homogeneity of plant life in Tehsil TakhtE-Nasrati, Pakistan. Global Journal of Science Frontier Research Agriculture \& Biology, 12, 6572.
Khanduri, V. P., Sharma, C. M., Kumat, K. S., \& Ghildiyah, S. K. (2013). Annual variation in flowering phenology, pollination, mating system, and pollen yield in two natural populations of Schima wallichii (DC.) Korth. The Scientific World Journal, 2013, 1-11.

Kusmana, C. (2017). Metode survey dan interpretasi data vegetasi. Bogor: IPB Pr.

Kusumastuti, A. (2017). Struktur vegetasi dan pola sebaran Schima wallichii di Resort Kemalang Taman Nasional Gunung Merapi pasca erupsi 2010 (Unpublished bachelor's thesis). Universitas Gadjah Mada, Yogyakarta, Indonesia.

MMNP. (2011a). Restorasi ekosistem Taman Nasional Gunung Merapi pascaerupsi 2010. Yogyakarta, Indonesia: Directorate General of Forest Protection and Nature Conservation, Mount Merapi National Park.

MMNP. (2011b). Survey kondisi tumbuhan dan satwa liar Taman Nasional Gunung Merapi pascaerupsi 2010. Yogyakarta: Mount Merapi National Park.

Natalia, D., \& Handayani, T. (2013). Analisis vegetasi strata semak di Plawangan Taman Nasional Gunung Merapi pasca erupsi merapi 2010. Jurnal Bioedukatika, 1(1), 62-71.

Raeval, V., Violle, C., \& Munoz, F. (2012). Mechanisms of ecological succession: insights from plant functional strategies. Oikos. 121, 1761-1770.

Rahayu, Ariyanto, D. P., Komariah, Hartati, S., Syamsiyah, J., \& Dewi, S. H. (2014). Effects of Merapi Mountain eruption on arable land and the efforts of rehabilitation. Caraka Tani, 29(1), 6172.

Rindrasih, E. (2013). The impact of environmental changes after Merapi eruption 2010 toward the image of tourism. Jurnal Nasional Pariwisata, 5(1), 1-13.

Roemantyo, Nastiti, A. S., \& Wiadnyana, N. N. (2012). Struktur dan komposisi vegetasi sekitar sarang penyu hijau (Cheloniamydas Linnaeus) Pantai Pangumbahan, Sukabumi Selatan, Jawa Barat. Berita Biologi, 11, 373-387.

Siswo, Yun, C. W., \& Abdiyani, A. (2019). Distribution of tree species around springs and treessprings interplay possibility in the springs area of Soloraya, Central Java, Indonesia. Forest Science and Technology, 1-12.

Solikin. (2015). Autoekologi Elephantopus scaber L. di Kebun Raya Purwodadi. Bioeksperimen, 1, 2432.

Suryawan, A., Kinho, J., \& Mayasari, A. (2013). Struktur dan sebaran jenis-jenis suku Euphorbiaceae di Cagar Alam Tangkoko, Bitung, Sulawesi Utara. Info BPK Manado, 3, 89-102.

Suryawan, D., Sutyarto, E., Umaya, R., Kurnia, A., \& Hadiyan, Y. (2015). Sebaran spesies asing invasif 
Acacia decurrens di kawasan Taman Nasional Gunung Merapi. Pros Sem Nas Masy Biodiv Indon, 1, 738-742.

Sutomo, \& Fardila, D. (2013). Floristic composition of groundcover vegetation after the 2010 pyroclastic fire on Mount Merapi. Jurnal Manajemen $\mathrm{Hu}$ tan Tropika, 19, 85-93.

Sutomo. (2019). Ecology and invasiveness potential of Acacia decurrens in several parts of Mount Merapi National Park Area Yogyakarta. Jurnal Metamorfosa, 6(1), 1-6.

Untoro, Y., Hikmat, A., \& Prasteyo, L. B. (2017). The spatial suitable habitat model of Acacia decurrens in Mount Merbabu National Park. Media Konservasi, 22(2), 49-63.

Utami, S. N. H., Purwanto, B. H., \& Marwasta, D. (2018). Land management for agriculture after the
2010 Merapi eruption. Journal of Agro Science, 6(1), 32-38.

Yulianto, F. (2014). Analisis risiko aliran piroklastik gunungapi merapi pasca erupsi 2010 menggunakan data penginderaan jauh dan sistem informasi geografis (Unpublished master's thesis). IPB University, Bogor, Indonesia.

Vaghasiya, P. M., Dhamsaniya, S., Paradva, B.R., \& Patel, R.M. (2015). Vegetation characteristics of Chapredi Reserve Forest of Bhuj-Kachchh, Gujarat. eJournal of Applied Forest Ecology, 3(1), 6573

Wardyaningrum, D. (2019). Communication of local people about myths of Mount Merapi disaster. Jurnal Komunikasi Indonesia, 8(1), 49-57. 